Tyndale Bulletin 68.1 (2017) 1-29

\title{
A NEW CODEX FROM THE SCRIBE BEHIND THE LENINGRAD CODEX: L17
}

\author{
Kim Phillips \\ (k.1.phillips.00@cantab.net)
}

\begin{abstract}
Summary
Samuel b. Jacob was the scribe responsible for the production of the so-called Leningrad Codex (Firkowich B19a), currently our earliest complete Masoretic Bible codex. This article demonstrates that another codex from the Firkowich Collection, containing the Former Prophets only, is also the work of Samuel b. Jacob, despite the lack of a colophon to this effect. The argument is based on a combination of eleven textual and para-textual features shared between these two manuscripts, and other manuscripts known to have been produced by the same scribe.
\end{abstract}

\section{Introduction to the Manuscript}

Together with the Cairo Genizah, the Firkowich Collection of Hebrew manuscripts housed in the Russian National Library is the most important trove of manuscripts for the study of the medieval text of the Hebrew Bible. EVR I Bibl. 80 and EVR I B 13 are sections from a single codex of the Former Prophets residing in that collection. When Yeivin was preparing his monumental work on the Aleppo Codex, he included this manuscript among those close to the Aleppo Codex, and labelled it L17. ${ }^{1}$ For some years this manuscript was only readily accessible via the microfilm collection in the National Library of Israel. In recent months, however, high-resolution digital images of many of

${ }^{1}$ Israel Yeivin, The Aleppo Codex of the Bible: A Study of its Vocalisation and Accentuation (Jerusalem: Magnes Press, 1968). 
these microfilms, including L17, have been made available online via the website of the National Library of Israel. ${ }^{2}$

It is the intention of this article to demonstrate that L17 is the work of Samuel b. Jacob, the scribe best known for writing the Leningrad Codex. As such, L17 is of great importance for our understanding of the practice of this celebrated scribe. ${ }^{3}$

L17 is a large-format, beautifully written manuscript of the Former Prophets. ${ }^{4}$ The biblical text is written three columns to the page, seventeen lines per column, in a large, highly accomplished hand; the written area is approximately $27 \mathrm{~cm} \times 28 \mathrm{~cm}(\mathrm{~h} \times \mathrm{w}){ }^{5}$ The text is heavily annotated with inter-columnar $\mathrm{mp}$, and $\mathrm{mm}$ in the top and bottom margins of the page. The extensive $\mathrm{mm}$ is written over two to five lines in each margin. Rarely, the $\mathrm{mm}$ is also written in the vertical outer margins of the page.

2 The two parts of the manuscript have been uploaded as separate entities, each with a catalogue note linking the one part to the other. EVR I Bibl. 80 contains the earlier part of the manuscript, uploaded as 135 images (including 4 images of front matter, and 3 images of back matter). The microfilm number is F 19278. EVR I B. 13 contains the latter part of the manuscript, uploaded as 243 images (including 4 images of front matter, and 2 images of back matter). The microfilm number is F 69751. For ease of reference, I have eschewed any attempt to renumber the folios across the two parts of the manuscript. Instead, I simply refer to the online image number. Thus, $35 /$ refers to image 35 of EVR I Bibl. 80, while 57/refers to image 57 of EVR I B. 13.

3 Abbreviations used throughout this paper are as follows:

mp: masora parva

$\mathrm{mm}$ : masora magna

A: Aleppo Codex

B: British Museum Or. 4445

C: Cairo Codex of the Prophets

S: Damascus Pentateuch

L: Leningrad Codex (Firkowich B 19a)

$\mathrm{S}^{1}$ : Sassoon 1053

D: Biblical text of the ben Hayyim edition of the Miqraot Gedolot, Venice, 1524-1525

For details concerning $\mathrm{A}, \mathrm{B}, \mathrm{C}, \mathrm{L}, \mathrm{S}$, and $\mathrm{S}^{1}$, see Israel Yeivin, Introduction to the Tiberian Masorah, ed. E. J. Revell, trans. E. J. Revell, The Society of Biblical Literature Masoretic Studies 5 (Missoula, Montana: Scholars Press, 1980), 15-22.

4 L17 has been described previously on several occasions: Ephraim Moses Pinner, Prospectus der der Odessaer Gesellschaft für Geschichte und Alterthümer gehörenden ältesten hebräischen und rabbinischen Manuscripte (Odessa: 1845), 39-40; Albert Harkavy and Hermann Leberecht Strack, Catalog der hebräischen und samaritanischen Handschriften der Kaiserlichen Öffentlichen Bibliothek in St. Petersburg: Band I. Der hebräischen Bibelhandschriften erster und zweiter Theil (St Petersburg: C. Ricker; Leipzig: J. C. Hinrichs, 1875), 102-105; Yeivin, Aleppo, 372.

5 Harkavy and Strack, Catalog, 103.For comparison: the text of L is written with 27 lines per column, with written area $20.5 \times 22 \mathrm{~cm}$. See Victor V. Lebedev, 'The Oldest Complete Codex of the Hebrew Bible', in The Leningrad Codex: A Facsimile Edition, ed. David Noel Freedman (Grand Rapids, Michigan: William B. Eerdmans, 1998), xxi. 
Due to the nature of the images, ${ }^{6}$ I have not been able to ascertain the orientation of the parchments (hair-flesh), or the precise details of the ruling and pricking, beyond the rudimentary observations that the pages are ruled horizontally and vertically, with vertical ruling of the left-hand margin as well as the right. The individual lines of masora magna are also ruled (e.g. 75/135).

Some of the quire numbers are visible:

\begin{tabular}{|c|c|c|c|c|c|c|}
\hline Image: & $75 / 135$ & $17 / 243$ & $37 / 243$ & $57 / 243$ & $77 / 243$ & $97 / 243$ \\
\hline Quire No.: & (trace) $\pi$ & יד (trace) & יה & יו & י & יח \\
\hline Image: & $118 / 243$ & $138 / 243$ & $159 / 243$ & $179 / 243$ & $203 / 243$ & \\
\hline o.: & יט & כ (trace) & 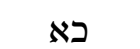 & כב (trace) & כג (trace) & \\
\hline
\end{tabular}

From this data it is possible to conclude that the manuscript originally consisted of 24 quires. As is typical of Oriental Hebrew codices, each quire was a quinion (five bifolia). ${ }^{7}$ It contained the entirety of Joshua to Kings, but not the Pentateuch, written over approximately 240 folios.

The present state of the manuscript is somewhat diminished. According to Harkavy and Strack, 61 of the folios are no longer extant. ${ }^{8}$ Moreover, three of the extant folios have clearly been written by another hand, and do not contain $\mathrm{mp}$ or mm: 23-24/243 (2 Sam. 13:18-36); 31-32/243 (2 Sam. 15:14-32); 61-62/243 (2 Sam. 24:117). ${ }^{9}$ In addition, many of the surviving folios are badly mutilated, particularly at the beginning and end of the first of the two parts of the codex (see images 7-16/135; 114-132/135).

The following table outlines the extant text of the manuscript according to the online images, excluding those parts added by a second hand:

Josh. 9:1-12:8

Josh. 22:8-Judg. 8:31
$5 / 135-16 / 135$

$17 / 135-54 / 135$

6 The online images are digitisations of the microfilms held in the National Library of Israel's Institute of Microfilmed Hebrew Manuscripts.

7 Malachi Beit-Arié, Hebrew Codicology: Historical and Comparative Typology of Medieval Hebrew Codices based on the Documentation of the Extant Dated Manuscripts until 1540 Using a Quantitative Approach: Preprint internet version 0.6 (2017), 223-24. Available at: http://web.nli.org.il/sites/NLI/Hebrew/collections/ manuscripts/hebrewcodicology/Documents/Hebrew-Codicology-continuouslyupdated-online-version.pdf.

8 Harkavy and Strack, Catalog, 103.

9 Harkavy and Strack, Catalog, 103. 
Judg. 15:1-1 Sam. 14:19 55/135-113/135

1 Sam. 29:7-2 Sam. 2:5 114/135-122/135

Correct order of images: 114, 115, 116, 117, $120=121,122,118,119$ (excipit: 2 Sam. 2:5)

2 Sam. 2:24-13:18

$123 / 135-22 / 243$

129 (2:24-3:2); 130 (3:2-12); 128 (3:12-18); 127 (3:23-29); 132 (3:29-38); 131 (4:2-8); $126(4: 8-$ $5: 3) ; 125$ (5:6-13); 124 (5:13-24); 123 (6:2-9).

From $1 / 243$ onwards consecutive order is resumed

2 Sam. 13:36-15:14 $25 / 243-30 / 243$

2 Sam. 15:32-24:1 $33 / 243-60 / 243$

2 Sam. 24:17$63 / 243-240=241 / 243$

2 Kgs 25:30

The question of the date of the manuscript is slightly complicated by the presence of a dated colophon (see 241/243):

Nehemiah b. R. Said of Erzerum

נחמיא בן ר סעיד ארזרומיי

bought this manuscript from Moses

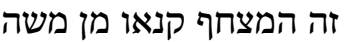

and Tobiah, two brothers, the sons of Eliah וטוביא שני אחים בני אליא the Chief Orkotos ${ }^{10}$ from Constantinople, הראש אורקוטו מן קוסטנדינא here, in the year 698 .

פה בשנת ת'ר'צ'ח'

If the date 'ת'ר'צ' is using the Creation system, this would correspond to the year $938 \mathrm{CE}$. Thus, the manuscript would have to have been written before this date. In their catalogue description of the manuscript, however, Harkavy and Strack express grave doubts about such a conclusion:

Das Epigraph ... macht nicht den Eindruck hohen Alters ... Der Codex selbst könnte am Ende des 10. oder im 11. Jahrhundert geschrieben sein. Gegen den Anfang des 10 Jahrh. (spätetestens [sic] diesen Entstehungstermin setzt das Epigraph voraus) spricht u. A. auch die mehrfache Citirung des Ben Ascher und des Ben Naphtali... Das Epigraph aber ist gewiss bedeutend jünger als die Handschrift. ${ }^{11}$

(The colophon ... does not give the impression of great age ... The codex itself could have been written at the end of the tenth century or during the eleventh century. The colophon presupposes the beginning of the tenth century, at the latest, as the production date of the codex, but the

\footnotetext{
${ }^{10}$ I am grateful to Professor Nicholas de Lange for the identification of this term.

11 Harkavy and Strack, Catalog, 105.
} 
repeated mentions of $b$. Asher and $b$. Naftali, among other factors, render this implausible ... At any rate, the colophon is certainly significantly later than the manuscript.)

Their reasoning is cogent: the multiple references to $b$. Asher and $b$. Naftali in the masora render it virtually impossible that the codex could have been written before $938 \mathrm{CE}$, as this would have been while $\mathrm{b}$. Asher was still alive, and possibly even before he had completed the Aleppo Codex. ${ }^{12}$ Rather, the end of the tenth century would appear to be the earliest possible date for the codex. Yeivin agrees, ${ }^{13}$ suggesting a date around $975 .{ }^{14}$

\section{Other Manuscripts Written by Samuel b. Jacob}

Before mounting the case that L17 is the work of Samuel b. Jacob, it will be useful briefly to review the other extant manuscripts known to have been written by him, in addition to the Leningrad Codex:

\section{2:1 Torah}

1. $\mathrm{L}^{\mathrm{m}}$ : this manuscript of the Torah is of particular significance due to the large proportion of Babylonian masora preserved in its masora magna.

2. T-S A2.46/A3.35: these two single folios from the Cairo Genizah have been suggested by the present writer, using arguments very similar to those employed below, to be the work of Samuel b. Jacob. ${ }^{16}$ These fragments are particularly

12 Assuming, for now, the veracity of the claim of the later colophon once attached to the Aleppo Codex.

13 Yeivin, Introduction, 27.

14 Dr Ben Outhwaite (private communication, 6 April 2017) has confirmed the lateness of the colophon, and suggested that the date 'ת'ר'צ' may be using the Seleucid system. In this case, (1)698 would correspond to 1387 CE. Such a date would fit with the spelling of the names in the colophon, which, according to Outhwaite, postdate the spelling practices of the classical Genizah period.

15 Mordechai Breuer, ed., The Masorah Magna to the Pentateuch by Shemuel ben Ya'aqov $\left(M s . L^{m}\right), 2$ vols, The Manfred and Anne Lehmann Foundation Series 16 (New York: Manfred and Anne Lehmann Foundation, 1992). See also Yosef Ofer, The Babylonian Masora of the Pentateuch: Its Principles and Methods, The Academy of the Hebrew Language: Sources and Studies VI: A New Series (Jerusalem: Magnes Press, 2001), 13-25.

16 Kim Phillips, 'Two New Fragments from the Scribe behind the Leningrad Codex', in Research Approaches in Hebrew Bible Manuscript Studies: Proceedings of the EAJS LAB Conference, 6-8 June 2016, Aix-en-Provence (Studies in Jewish History and Culture; Leiden: Brill, forthcoming), n.p.p. The structure of much of the current paper borrows heavily from this article, though superseding it in many details. 
significant in that the $\mathrm{mm}$ therein is identical to that found in $\mathrm{L}^{\mathrm{m}} \cdot{ }^{17}$

3. A single leaf from Genesis $26 .^{18}$

4. $\mathrm{L}^{\mathrm{s}}$ : a Torah codex containing Saadia's Tafsìr. The mm of this codex, too, is significant, in that Samuel b. Jacob has worked into it many entries from Menahem b. Saruq's well-known dictionary: Mahberet Menahem. ${ }^{19}$

5. T-S AS 72:79 and T-S Ar 1a.38: these fragments preserve parts of Exodus with Saadia's Tafsitr, similar to L ${ }^{\mathrm{S}}{ }^{20}$

\section{2:2 Prophets}

Of particular relevance for this article is the manuscript variously referred to as Gottheil 27, $\mathrm{L}^{\mathrm{m}}$, or 2 p. This, like L17, is a manuscript of the Former Prophets: Joshua-Kings. It was examined by Gottheil in or before 1905 in the Karaite synagogue in Cairo. ${ }^{21}$ Gottheil records the first-person colophon, in which Samuel b. Jacob claims to have written, pointed, and annotated the codex with masora. This colophon has subsequently been lost. Breuer labels both this manuscript, and the first manuscript in the list above, as $\mathrm{L}^{\mathrm{m}}$.2 Though the main body of Breuer's monograph pertains to the masora magna of the Torah codex only, he devotes attention to certain features of the codex of the Former Prophets in the introduction to the monograph. Yeivin, in recognition of the fact that originally this codex of the Former Prophets was distinct from the Torah codex now referred to as $\mathrm{L}^{\mathrm{m}}$, renames the Former Prophets codex as $2 \mathrm{p}^{23} \mathrm{We}$ adhere to Yeivin's terminology below.

Gottheil begins his description of 2 p as follows:

17 Kim Phillips, 'The Masora Magna of Two Biblical Fragments from the Cairo Genizah, and the Unusual Practice of the Scribe behind the Leningrad Codex', Tyndale Bulletin 67.2 (2016), 287-307.

18 Ofer, Babylonian, 25, n. 30.

19 Yosef Ofer, 'A Masoretic Reworking of Maḥberet Menahem', Leshonenu 62 (1999), 189-255.

20 See Ronny Vollandt, 'Two fragments (T-S AS 72.79 and T-S Ar.1a.38) of Saadiah's Tafsīr by Samuel ben Jacob,' Fragment of the Month (November 2009), n.p. Cited 1 April 2016. Online: http://www.lib.cam.ac.uk/Taylor-Schechter/fotm/ november-2009/.

21 Richard Gottheil, 'Some Hebrew Manuscripts in Cairo', JQR 17, no. 4 (1905), 63637.

22 Breuer, $L^{m}$, $i x$.

23 Israel Yeivin, 'A Biblical Manuscript very close to the Aleppo Codex: L11', Textus 12 (1985), לא. 
In the Karaite Synagogue: part of a Bible MS.; $43 \times 383 / 4 \mathrm{~cm}$., parchment, magnificently written in beautiful characters, three columns to the page, plentiful Masora; containing Joshua, Judges, Samuel and Kings complete; going to pieces because of dampness, the last pages look like a mass of Genizah ruin. ${ }^{24}$

This accords so precisely with the description of L17 that one may wonder if, in fact, L17 and 2 p are the same manuscript. This, however, cannot be the case. Yeivin, in a brief description, notes that 2 pas 19 lines per column, unlike L17's 17 lines per column. ${ }^{25}$ Moreover, L17 was already in St Petersburg by 1875 when it was described by Harkavy and Strack, whereas $2 p$ was still in the Karaite synagogue in Cairo in 1941, where it was photographed by a delegation from Jerusalem. ${ }^{26}$

Thus, if the arguments for Samuel b. Jacob's authorship of L17 prove convincing, L17 and 2 thereby become sister manuscripts: both high-quality manuscripts of the Former Prophets, written by Samuel $b$. Jacob, inviting comparison between the two. ${ }^{27}$ We attempt the beginnings of such a comparison below. First, though, must come the arguments for Samuel b. Jacob's authorship of L17.

\section{Identifying the Manuscript as the Work of Samuel b. Jacob}

L17 can be shown, to a high degree of probability, to be the work of Samuel b. Jacob. In the absence of a colophon, such identifications can be made on the basis of a cluster of identifying features, in addition to palaeographic considerations. No single criterion is decisive in itself, but the cumulative evidence is compelling. The discussion below is divided into three parts. The masora magna is a significant place where the individual identity of a scribe can find expression. Beit-Arié claims that, typically, medieval Hebrew scribes left idiosyncratic traces in the

24 Gottheil, Manuscripts, 636.

25 See 188-89 of Israel Yeivin, 'A Biblical Manuscript very close to the Aleppo Codex from the Karaite Synagogue in Cairo (C1)', in Studies in Bible and Exegesis, Vol. III: Moshe Goshen-Gottstein-in Memoriam, eds Moshe Bar-Asher, Moshe Garsiel, Devorah Dimant, and Yeshayahu Maori (Ramat Gan: Bar-Ilan University Press, 1993), 169-94.

26 Ofer, Babylonian, 24, n.25.

27 Furthermore, the possibility is raised that L17 and 2 pay be the two manuscripts of the Prophets mentioned in T-S 10J5.15. See Phillips, Unusual, 304-306. 
'graphic elements which accompany the script letters'. ${ }^{28}$ Five such para-textual features concerning the writing of the $\mathrm{mm}$ are discussed first. Then follows a discussion of three further para-textual features pertaining to the main body of the biblical text. This leads, lastly, to a discussion of three aspects of the writing of the biblical text itself.

\section{3:1 Para-Textual Features in the Masora Magna}

\section{The Layout of the Masora Magna}

Ofer notes a distinctive aspect of the layout of the $\mathrm{mm}$ in both $\mathrm{L}$ and $\mathrm{L}^{\mathrm{m}} \cdot{ }^{29}$ In a great many cases the mm surrounds the three columns of the biblical text thus:
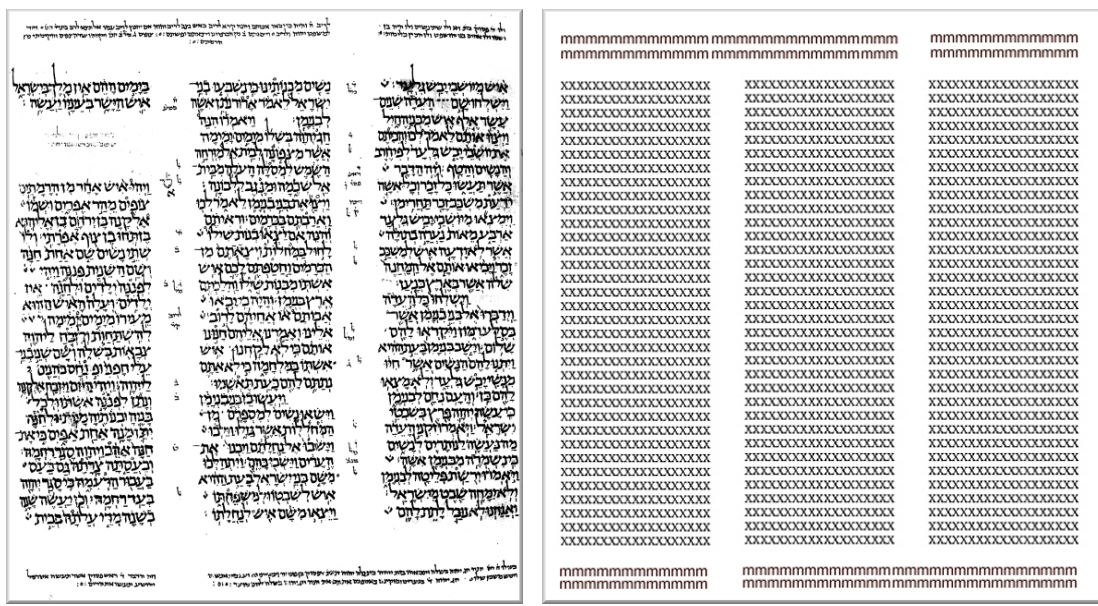

A typical page from L, illustrating the distinctive layout of the $\mathrm{mm}$.

At the top, the $\mathrm{mm}$ is written over the first column in isolation and then continuously over the second and third columns $(1,2)$. This pattern is then reversed in the lower row of $\mathrm{mm}(2,1)$. The mirror image of this layout is found on many other pages: $(2,1)$ at the top; $(1,2)$ at the bottom. ${ }^{30}$

28 Malachi Beit-Arié, The Makings of the Medieval Hebrew Book: Studies in Palaeography and Codicology (Jerusalem: Magnes Press, 1993), 79.

29 Ofer, Babylonian, 14.

30 This pattern only pertains to the three-column sections of Samuel b. Jacob's scribal work. For details of his approach in the poetic books (Job, Proverbs, and Psalms), with their two-column layout, see Ofer, Babylonian, 14. 
In $\mathrm{L}$ this layout is prevalent, but not ubiquitous. For example: of the 74 pages over which the text of 1-2 Kings is written, 22 pages do not follow this pattern ( $70 \%$ conformity to the pattern). In the 90 pages over which 1 Kings is written in L17, only 14 do not follow the pattern ( $84 \%$ conformity to the pattern).

\section{The Masora Magna Ornament}

Commonly, in Bible codices containing $\mathrm{mm}$, the scribe employs some sort of pattern or geometric design as an ornament with which to separate distinct masoretic notes. These ornaments are often also used at the end of each block of text, sometimes to achieve left justification. The most common ornament appears to be a simple circule (as with the Aleppo Codex). Not infrequently, however, more distinctive or idiosyncratic ornaments appear. Consider the example appearing at the end of the following masoretic note:

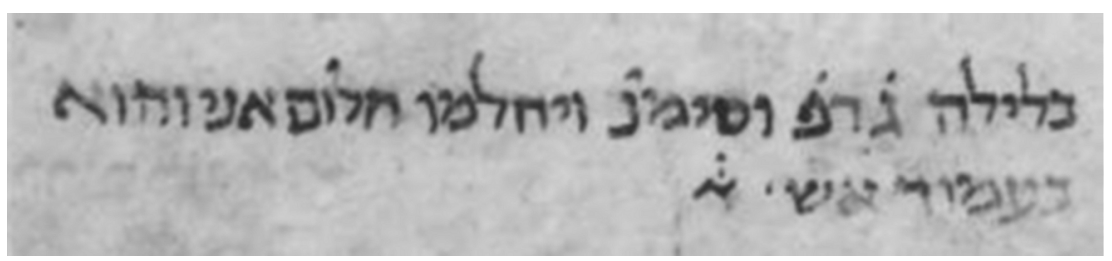

Mm ornament from T-S A1.30 31

In L, Samuel b. Jacob ubiquitously employs a colon-circule-colon symbol (:o:) symbol. It is used both to separate distinct masoretic notes, and at the end of each block of $\mathrm{mm}$. Often, a sequence of colons and circules (:0:0:0:0:) is used as a mm left justifier. It is also found in the other texts written by Samuel b. Jacob, for which images are currently available, including T-S A2.46 and T-S A3.35. ${ }^{32}$ It appears to have been his default symbol for separating masoretic notes, and for use at the end of each block of notes, though he occasionally replaced it with a simple colon, when space and left justification demanded.

31 Images from the Taylor-Schechter Genizah Collection are reproduced by kind permission of the Syndics of Cambridge University Library.

32 Namely, the codex of the Pentateuch containing Saadia's $\operatorname{Tafsir}\left(\mathrm{L}^{\mathrm{s}}\right)$, held in the National Library of Russia (Evr. II C 1/). NB: an image of this manuscript is available on the website of the National Library of Russia. The :o: symbol is clearly visible on f.2r. Likewise, T-S Ar.1a.38 - a fragment from another copy of the same work by Samuel b. Jacob-reveals the same symbol. The leaf of Genesis 26 (number 3 in the list above) also contains the symbol. 


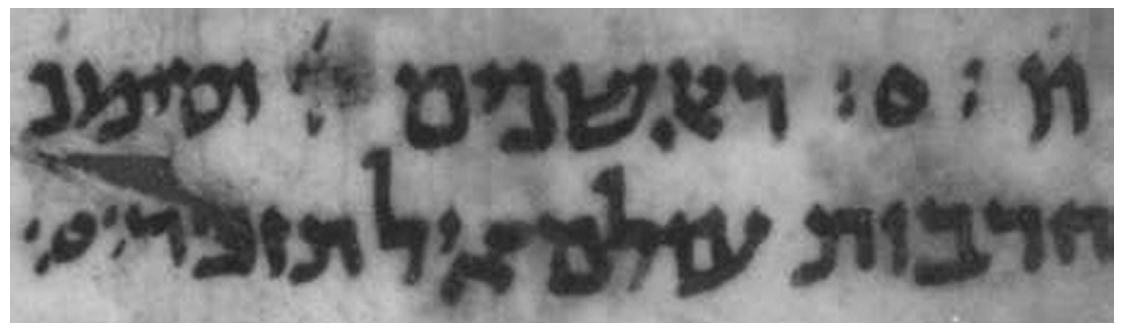

Ornament from mm of T-S A3.35: the colon-circule-colon pattern can be seen here between distinct Masoretic notes, and at the end of the note.

Within the fragments of the Taylor-Schechter Genizah collection, this colon-circule-colon ornament is an unusual configuration. Of a sample of 110 manuscripts containing $\mathrm{mm}$, from which the pertinent information could be gleaned, ${ }^{33}$ only 8 contained this ornament, including T-S A2.46 and A3.35, which are certainly Samuel b. Jacob's work.

In L17, the colon-circule-colon symbol is once again ubiquitous, both between distinct masoretic notes written as part of the same masora block, and at the end of each block of notes. Moreover, the repeated pattern :0:0:0:o: frequently appears for the purposes of left justification of masora blocks (e.g. 157/243; 158/243; 160/243). ${ }^{34}$

In L17, however, an additional pattern is also used. This pattern resembles small diamond shapes, linked by a roughly drawn horizontal line. It is not very common in L17; its use is apparently limited to when a long filler is required to achieve left justification of the masoretic notes. ${ }^{35}$ I have found, without conducting an exhaustive search, one example of this same pattern used in L, at the top left of f. 135v:

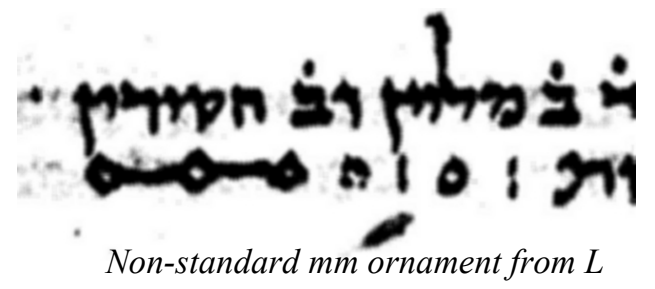

33 That is, the only manuscripts included in the sample were those where sufficient $\mathrm{mm}$ was visible to ascertain whether ornaments were used at all, and if so, the configuration of the ornament.

${ }^{34}$ Unfortunately, the access rights pertaining to this manuscript prohibit the publishing of any images therefrom.

35 See, for example: $18 / 135 ; 20 / 135 ; 27 / 135 ; 38 / 135 ; 117 / 243 ; 126 / 243 ; 160 / 243$; $162 / 243 ; 200 / 243$. 
Thus, the use of this pattern in L17 does not cast doubt regarding the attribution of the codex to Samuel b. Jacob. However, the relative frequency of its use in $\mathrm{L} 17$ compared with $\mathrm{L}$ requires explanation.

\section{Centre Justification of the Final Part-Lines of Masora Magna}

A further very pronounced tendency is visible within Samuel b. Jacob's $\mathrm{mm}$, as exemplified in L. When the block of $\mathrm{mm}$ consists of two rows or fewer, these rows are almost always right justified. However, if the block of $\mathrm{mm}$ consists of three or more rows, the final part-line is regularly centre justified. Almost any folio of $\mathrm{L}$ demonstrates this tendency, as do T-S A2.46 and T-S A3.35. ${ }^{36}$ The Aleppo Codex, by contrast, regularly right justifies final part-lines. Indeed, of the sample of 110 Taylor-Schechter manuscripts, centre justification of final partlines was only found in 5 cases, including T-S A2.46 and A3.35:

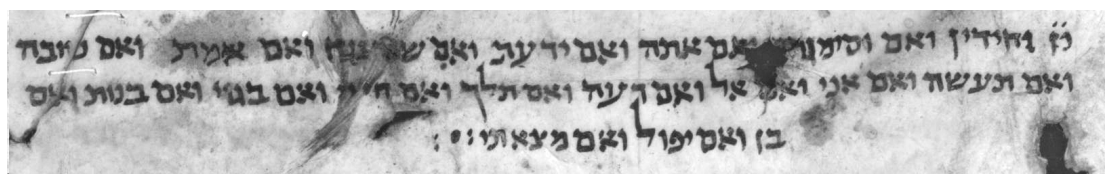

Centre justification of third row final part-line in lower mm of T-S A3.35

Though a very regular tendency, there are some exceptions to this rule in $\mathrm{L}$, where a third or fourth part-line of masora is right justified rather than centre justified (e.g. 157r; 247r).

As expected, this tendency towards centre justification is certainly the norm, too, in L17, under the very same conditions. Notwithstanding, there appear to be more exceptions to this rule in L17 than one finds in L. For example, at 44/135, 45/135, and 163/243 masora blocks consisting of three lines each have the final line right justified. However, the masora of L17 is much fuller than in L: a great many masora blocks consist of three or more lines. Thus, the apparent increase of right justified third or fourth part-lines may simply be due to the fact that there are more opportunities for such deviation from the norm.

\section{Methods for Left Justification of the Masora Magna}

Above, it was described how Samuel b. Jacob typically writes his $\mathrm{mm}$ in four blocks on each three-column page. His preference (according to L) was to justify the left-hand margin of these blocks as far as possible.

36 It is also apparent in the aforementioned image of $\mathrm{L}^{\mathrm{s}}$ (see $\mathrm{n} .31$ above). 
As already noted, one tool for this purpose was his use of the :o: symbol, often repeated in series. In addition, he employed frequent use of abbreviation of words. Among a variety of additional techniques found in the $\mathrm{mm}$ of $\mathrm{L}$, perhaps the most unexpected (due to its total absence from the writing of the biblical text itself, as discussed below) is his use of dilatation of letters containing horizontal bars: e.g. f. $28 \mathrm{r}$ (ת); f. 33r ( $\mathrm{r}$ and ); f. 44v (ר). This unexpected dilatation (together with all the less unexpected features) is also clearly visible in L17. Image 102/135, for example, contains dilatation of מ, מת all on a single page.

\section{Substitutions for the Tetragrammaton}

Beit-Arié suggests that the substitutions employed for the Tetragrammaton are another feature of a scribe's individuality that, in combination with other features, can be used to identity a particular scribe.$^{37}$ Moreover, he claims that such features tend to remain stable throughout the lifetime of a given scribe. ${ }^{38}$

In L Samuel b. Jacob uses two different substitutions for the Tetragrammaton: (i) two horizontally adjacent yods, with a central supra-linear dot; (ii) two horizontally adjacent yods, with a supra-linear dot. However, the left hand yod is written with a flourish such that it resembles a cursively written tet. Sometimes the topmost extremity of the flourish joins up with the supra-linear dot, and sometimes not. ${ }^{39}$

L17 employs this same pair of substitutions (e.g. type (i), 31/135; type (ii), 32/135), though with an apparent preference for type (i). ${ }^{40}$

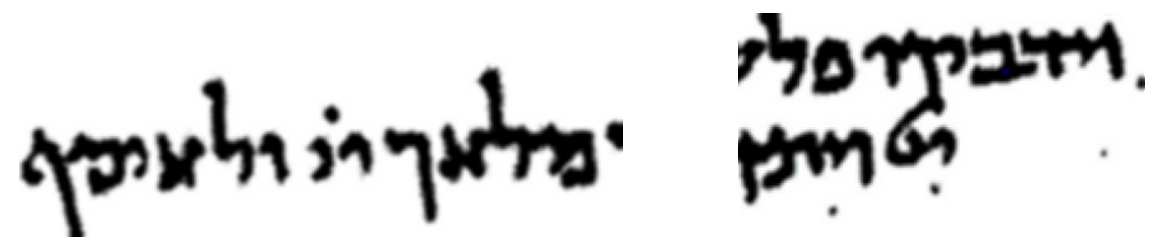

Tetragrammaton substitution written simply (left) and with a flourish (right)

37 Beit-Arié, Makings, 87.

38 Beit-Arié, Makings, 90-92.

39 In the first 20 folios of L, there are approximately 8 type (i) substitutions, and approximately 9 type (ii) substitutions.

40 From a sample of 17 such substitutions in L17, 13 were type (i). 


\section{3:2 Other Para-Textual Features}

The features above all pertain to the writing of the $\mathrm{mm}$, while the following pertain to para-textual features of the biblical text itself.

\section{Seder Markers}

L appears to have at least two classes of seder markers: an unornate enlarged $\delta$ (frequently with the addition of a transverse $T$ shape above the $\delta$ symbol), and a slightly more ornate symbol, usually with a circule in the middle of the symbol and simple ornamentation over the top. The ornate seder marker is also found in T-S A2.46 and L $\mathrm{L}^{\mathrm{s}}$ :
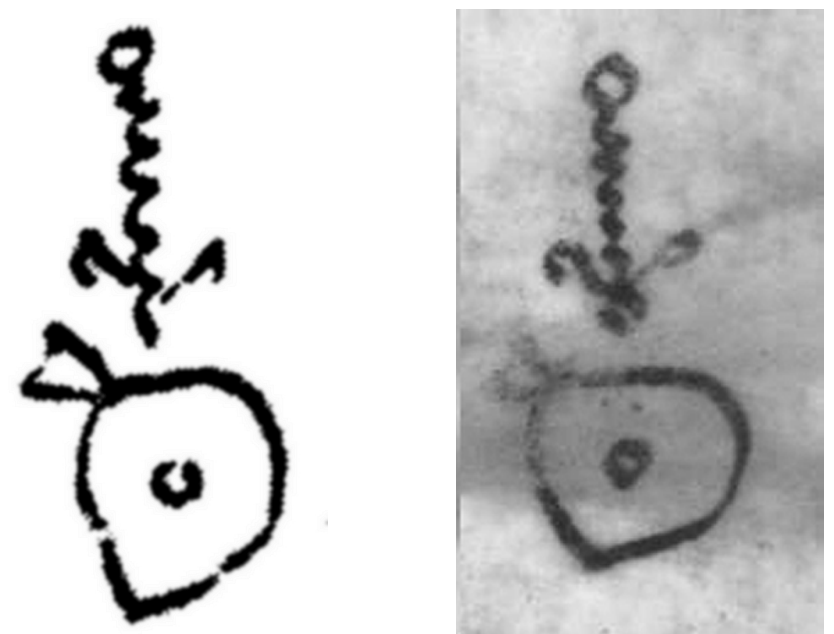

Ornate seder marker from Lf.71v (left), and from T-S A2.46 (right)

In $\mathrm{L}$ there is a degree of stylistic variation in these ornate seder markers, particularly in the precise details of the ornamentation over the top of the $\boldsymbol{D}$. Nonetheless, they form a coherent group.

The seder markers in L17 are very similar to L's ornate seder markers. They share the same basic elements: the small circule in the $D$; the wedge shape forming the top left stroke of the $D$; the simple ornamentation over the top of the $D$. Moreover, they share a similar degree of free variation within these constraints. ${ }^{41}$

41 As can be seen be examining the first ten extant seder markers of the manuscript: $12 / 135 ; 20 / 135 ; 31 / 135 ; 37 / 135 ; 43 / 135 ; 48 / 135 ; 52 / 135 ; 68 / 135 ; 72 / 135 ; 81 / 135$. The marker at $31 / 135$ is virtually identical to the images above. 


\section{Left Justification}

Early Oriental Bible codices often show non-strict attempts to justify the left margin of each column of the biblical text. Many methods were available to the scribe for this purpose: dilatation of certain letters (particularly final mem or tav); sequences of raised dots at the end of the line, or in between words in the middle of the line; strokes ordinarily forming the first part of certain letters (frequently the first stroke of the alef); the writing out of letters that would become the first letters of the initial word on the next line. Beit-Arié notes that, having chosen a set of devices for left justification, a scribe will normally adhere to them consistently. ${ }^{42}$ The original scribe behind $\mathrm{B}$, for example, predominantly used raised dots at the end of the line, raised dots between the last words of a line, the first stroke(s) of the alef, and (much less frequently), part of the letter forming the first letter of the first word of the following line. The approach of the scribe behind $\mathrm{S}$, by contrast, was quite different. He had two basic fillers: the right-hand half of the letter shin, and what looks like the top half of a supralinear alef, with a dot in the cleft. If space permitted, he frequently wrote the first letter(s) of the first word of the following line before the half-shin or half-alef (particularly the former).

Samuel b. Jacob's method (as exemplified in L) was different again, and no less distinctive. He occasionally used raised dots between the final words of the line, or at the end of a line. More usually, however, he used dotted part-letters. The upper part of the letter alef appears to have been his default filler shape. However, fairly frequently (especially if the letter matched the first letter on the following line) he would use combinations of the following letters (each of which was dotted, and reproduced only in part): ש מ א ל. Is it coincidence that these letters are the consonants of the name שִשמוּאִ מִ Or perhaps this is a play on the fact that such fillers only occur on the left margin of a column?

L17 shows precisely the same method as seen in $\mathrm{L}$ in terms of the range of fillers employed. However, there is a less pronounced preference for the dotted part-alef, and a tendency towards more even use of each of the letters שש מאל.

42 Beit-Arié, Makings, 82-84. 


\section{Parashah Petuhah at the Top or Bottom of a Column}

When a scribe wished to mark a parashah petuhah, yet had finished the foregoing text at the end of the previous line, he would leave an entire blank line before resuming the text at the beginning of the line thereafter. If this blank line happened to be the first or last line of a column, the danger arose of the pisqah being overlooked, or misinterpreted. Ofer notes that in L Samuel b. Jacob avoided this danger by marking the blank line (when it occurred at the head or tail of a column) with a dotted pe at the beginning, middle, or beginning and end of the line: ${ }^{43}$

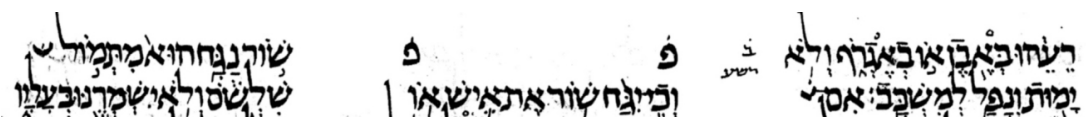

Parashah petuhah indicators at the top off. $44 \mathrm{r}$ in $L$

Ofer elsewhere notes that Samuel b. Jacob employed this latter method ( $p e$ at the beginning and end of the line) when writing the other codex of the former prophets: $2 p .^{44}$

In L17, too, this same method (pe at the beginning and end of the blank line) is consistently employed. ${ }^{45}$ Of the eight manuscripts that Ofer discusses in this regard (including L, but not including 2 p or L17), $\mathrm{L}$ is the only manuscript to mark these blank lines in this manner. ${ }^{46} \mathrm{We}$ can therefore summarise the findings as follows: from a sample of 10 of the most ancient Tiberian Bible codices, L, 2 p and L17 alone share the common practice of marking these blank lines with two, dotted pes.

\section{3:3 Textual Features}

The features above have all been concerned with para-textual detailsdetails unrelated to the writing of the biblical text itself. This is to be expected. By the eleventh century the details of the Tiberian biblical text had been rigidly standardised even down to the fine details of vocalisation and accentuation, leaving little room for scribal individuality to be expressed. Nonetheless, at least three types of textual differences remain between the earliest and best Tiberian Bible

\footnotetext{
43 See p. 96 of Yosef Ofer, 'Masoretic Matters-the Marking of the Parashiyyot', Megadim 2 (1986-1987), 91-104.

44 Ofer, Babylonian, 25.

45 See, for example, $12 / 135 ; 16 / 135 ; 125 / 243 ; 165 / 243 ; 176 / 243 ; 178 / 243$; $188 / 243$.

46 Ofer, 'Parashiyyot', 95-100.
} 
codices. First, differences between codices arose through inevitable copying error. Second, differences arose when individual scribes transmitted particular traditions they had received pertaining to some word or detail of the text. Finally, differences arose between codices as a result of the non-standardisation of some of the most fine-grained details of the vocalisation and accentuation of the biblical text. The first two case studies below, I will suggest, are best explained as traditions transmitted by Samuel b. Jacob. The third case study is an example of where lack of standardisation of minutiae allowed room for individual scribal preference.

\section{The Jerahmeelites}

At 1 Samuel 27:10 $\mathrm{L}$ has the apparently nonsensical reading

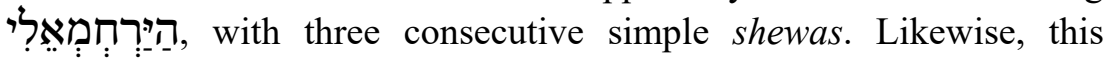
reading was apparently also original to 1 Samuel $30: 29$, though it has been emended subsequently (traces of the original shewa are still visible beneath the resh, and the vellum has clearly been rubbed at that point). Breuer notes that in $2 \mathrm{p}$, as well, this unusual pointing is found at 1 Samuel 27:10 (he does not comment on 1 Sam. 30:29). ${ }^{47}$ By contrast,

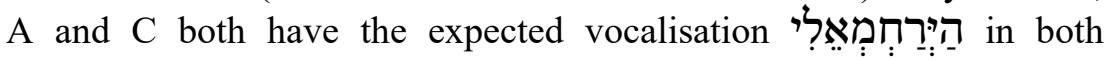
locations.

1 Samuel 27:10 is not extant in L17, but 1 Samuel 30:29 is. There,

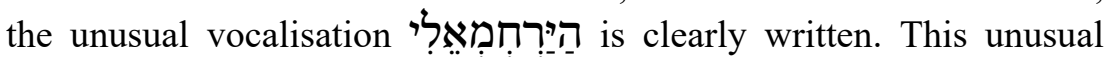
vocalisation, then, appears in two manuscripts that are unquestionably Samuel b. Jacob's work (L and 2p). Its appearance in this third manuscript, L17, must be considered strong evidence that the same hand was at work here. Moreover, it must be considered strong evidence that this hand intended this reading: this is not a case of unintentional error.

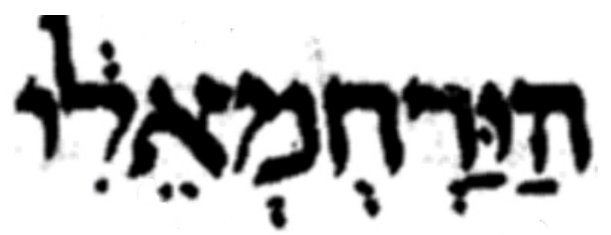

Three consecutive simple shewas in "Jerahmeelites" at 1 Samuel 27:10 in L

47 Breuer, $L^{m}$, xvii. 


\section{Issachar}

Breuer notes that one of the unusual features of the pointing of $\mathrm{L}$ is the frequency with which the dagesh in the name יששכר is omitted. He finds this same omission frequently in $\mathrm{L}^{\mathrm{m}}$ (referring, apparently, to both $\mathrm{L}^{\mathrm{m}}$ proper, and to 2 ). ${ }^{48}$ Likewise, Ofer reports the same phenomenon in $\mathrm{L}^{\mathrm{s}}{ }^{49}$ Thus, this idiosyncrasy appears to be a trait common to manuscripts known to have been written by Samuel $b$. Jacob.

In L17 only four occurrences of the name occur due to the large lacunae in the books of Joshua and Judges: Judges 5:15 $\times 2$; 1 Kings

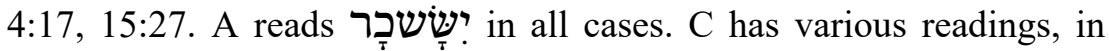
keeping with its reputation as a Ben Naphtali-esqe codex. All its readings, however, have the dagesh. $\mathrm{L}$ and $\mathrm{L} 17$ have identical patterns:

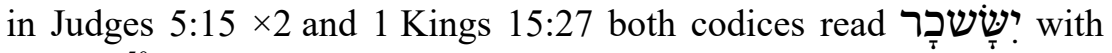
dagesh $;^{50}$ in 1 Kings $4: 17$ both miss out the dagesh.

As Dotan has shown, ${ }^{51}$ L's tendency towards omission of the dagesh is non-random; rather, it recurs in clearly definable phonetic contexts. The evidence presented here bolsters Dotan's conclusion; in the case of the word יששכר, Samuel b. Jacob appears to have been transmitting a tradition rather than simply erring.

\section{Rafe}

The extent to which rafe is used, and the precise details of use, varies widely among the great Masoretic codices. For example, the scribe behind $\mathrm{B}$ was very diligent in marking virtually all spirantized begadkfat letters with rafe. Likewise, he was assiduous in marking non-consonantal final he with rafe. The scribe behind $\mathrm{S}$ employed the rafe far more extensively, over a wider range of letters. ${ }^{52} \mathrm{By}$ comparison, Samuel b. Jacob's practice in L is more sparing. His general practice is to mark spirantized begadkfat letters with rafe, but

\footnotetext{
48 Breuer, $L^{m}$, xv. This is part of a broader pattern regarding L's rather idiosyncratic treatment of the dagesh. See Aron Dotan, 'Deviation in Gemination in the Tiberian Vocalisation', Estudios Masoreticos: V Congreso de la IOMS, ed. E. FernándezTejero, Textos y Estudios 'Cardenal Cisneros' 33 (Madrid: CSIC, 1983), 63-77.

49 Ofer, 'Maḥberet', 193, n.15.

50 In L17 both occurrences of the word in Judges 5:15 have clearly been tampered

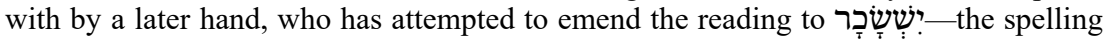
Mishael b. Uzziel attributes to Ben Naftali. See page 16 of Lazar Lipschütz, 'Kitāb alKhilaf: The Book of the Hillufim', Textus 4 (1964), 1-29.

51 Dotan, 'Gemination'.

52 See Yeivin, Introduction, 286-87.
} 
examination of virtually any line in the codex will reveal an exception. He shows a distinct tendency not to mark a spirant with rafe, if the letter already carries a supra-linear accent. By contrast, he almost always marks the rafe over two adjacent spirants (a single rafe, centrally placed). He inconsistently marks quiescent alef with rafe. ${ }^{53}$ He appears more consistent in not marking non-consonantal final he with rafe, as many manuscripts do, yet even here one finds exceptions.

The occurrences of rafe in 2 Kings 4 ( 44 verses) were examined in L, L17 and A. The results are as follows:

$\begin{array}{lcccc}\text { Use over } & \begin{array}{c}\text { Non-consonantal } \\ \text { final }\end{array} & \begin{array}{c}\text { Quiescent } \\ \text { begadkfat letters }\end{array} & \text { ?! } \\ \text { L } & 25 & 1 & 4 & 2 \\ \text { L17 } & 119 & 5 & 35 & 2 \\ \text { A } & 100 & 15 & 46 & 0\end{array}$

Prima facie, the most striking aspect of this data is L17's markedly greater use of rafe compared to L. This may be due, in part, to the increased space available in L17, which has only 17 lines per $27 \mathrm{~cm}^{54}$ column, as compared to L's 27 lines per $20.5 \mathrm{~cm}$ column.

Notwithstanding this difference, there are some notable similarities in the proportions of the two sets of data. In $\mathrm{L}$, the ratio of rafe use between non-consonantal final he, and begadkfat letters is 1:25, i.e. 0.040. In L17, the same ratio is $5: 119$, i.e. 0.042 . This remarkably similar ratio stands in stark contrast with the same ratio for A: 15:100, i.e. 0.150 . Thus, $\mathrm{L}$ and $\mathrm{L} 17$ show a markedly similar tendency not to use rafe on non-consonantal final he, while A is nearly four times more likely to do so.

The use of rafe over quiescent alef is also instructive. In $\mathrm{L}$, the ratio of rafe use between quiescent alef and begadkfat letters is $4: 25$, i.e. 0.16. In L17 the same ratio is $35: 119$, i.e. 0.29 . In A the same ratio is 46:100, i.e. 0.46. In L17, then, the scribe shows a much greater tendency to mark quiescent alef than is found in L. Nonetheless, this tendency is far less pronounced than that of A.

53 A ready example of his inconsistency here can be seen in Exodus 32:21-22 (in L). In the phrase ויאמר משה (v.21) b. Jacob marks the alef with rafe, but in the phrase ויאמר אהרן (v.22) there is no such rafe.

54 Harkavy and Strack, Catalog, 103. 


\section{Conclusion}

How high ought the bar of 'proof' be set in these questions of authorship? Above, I have presented twelve separate lines of evidence, all converging towards the same conclusion: L17 is the work of Samuel b. Jacob. Other lines of evidence could have been added: the orientation of the segolta accent, or the details of use of the pashta accent, for example. Do these data constitute an iron-clad proof, a mere general plausibility, or something in between?

Iron-clad proofs are surely unattainable in questions of this nature. Nonetheless, I suggest that the data above constitute very strong evidence indeed for the claim made, as the following statistical observations show. Above, when discussing Samuel b. Jacob's use of the mm ornament :o:, it was noted that from a sample of 110 genizah Bible fragments containing $\mathrm{mm}$, only 8 contained this distinctive pattern. Likewise, the same sample of 110 fragments revealed only 5 that employed the technique of centre justification of final part-lines of the mm. In Ofer's sample of eight manuscripts, moreover, only one (L) marked the column-head or column-tail blank-line petuhah with the double 9 symbol. Thus, the probability of any given manuscript randomly containing all three features is very low indeed: $8 / 110 \times$ $5 / 110 \times 1 / 8=0.0004$. Doubtless, such a statistic must be treated with the utmost caution. ${ }^{55}$ Nevertheless, it serves an illustrative purpose. If the collocation of just these three features is rather unusual, how much more unlikely is the chance collocation of all eleven features discussed above. I contend, therefore, on the evidence of the eleven features discussed above, that L17 is almost certainly the work of Samuel b. Jacob.

With the question of authorship firmly established, we are enabled to begin the more interesting study of comparing different works produced by Samuel b. Jacob. Such comparative study has the potential to further our understanding of both L17 and L. For the first time (for scholars outside Israel and Russia) it is possible to contextualise the

55 First, it would be very difficult indeed to prove that this sample is representative of, say, Oriental Tiberian Hebrew model Bible codices from the tenth and eleventh centuries as a whole. More particularly, though, such statistical reasoning is only meaningful if the individual probabilities are independent of each other: that is, if the appearance of one feature renders it no more or less likely that one or both of the other features will also occur. On reflection, this seems rather improbable. For example, any scribe who had seen Samuel b. Jacob's work and wished to imitate it may have had an increased predisposition to combine these features. 
readings of $\mathrm{L}$ against the background of equivalent readings in other manuscripts known to have been written by Samuel b. Jacob. The ramifications of having this added dimension are potentially quite far reaching. For example, in a series of articles Dotan has discussed various archaic features of vocalisation and accentuation whose residue can be found in L, despite attempts to bring the pointing and cantillation of that manuscript into line with $b$. Asher's norms. ${ }^{56}$ Comparative study of other manuscripts also written by Samuel $b$. Jacob, therefore, has the potential to confirm, clarify, and expand these findings pertaining to early vocalisation traditions. More broadly, comparative study of Samuel b. Jacob's oeuvre will help to shed light on the scribal practices of the early post-masoretic era: for how long did original masoretic activity continue after Aaron b. Asher? Were Samuel b. Jacob and his contemporaries mere copyists? At a more conceptual level, such investigations could contribute to the complex issue of how we should conceive of the Standard Tiberian biblical tradition. Should all non-accidental divergences from A be considered 'failures', even when they do not contravene a masoretic note found in the same manuscript $?^{57}$ Even agreeing with Yeivin and Breuer that A represents the current closest approach to the centre of the Standard Tiberian circle, a fuller grasp of the area and perimeter of that circle remains a desideratum.

\section{Appendix: Initial Soundings Pertaining to the Consonantal Text of L17}

The detailed results arising from comparative study of Samuel b. Jacob's various Bible manuscripts must be the subject of future studies. Initial examinations of the consonantal text, vocalisation, accentuation, textual layout, and masoretic notes of L17 suggest that each of these

\footnotetext{
56 Aron Dotan, 'Residues of an Ancient Penultimate Stress in the Tiberian Tradition', in Hebrew Language Studies Presented to Professor Zeev Ben Hayyim, ed. Moshe Bar Asher (Jerusalem: Magnes Press, 1983), 143-60; Dotan, 'Gemination'; Aron Dotan, 'Pathé Hațfin: A Study of the Early Stages of Vocalisation', in Festschrift for Abraham Even Shoshan: Studies in Language, Bible, Literature and Culture, ed. B. Z. Luria (Jerusalem: Kiryat Sefer, 1985), 157-65.

57 For an influential attempt to abolish the idea of a single, monolithic Masoretic Text, and to speak instead of multiple local traditions, see Harry M. Orlinsky, prolegomenon to Christian David Ginsburg, Introduction to the Masoretico-Critical Edition of the Hebrew Bible (1897; repr., New York: Ktav, 1966).
} 
areas will prove fruitful in terms of expanding our understanding of $b$. Jacob as a scribe, and the texts he produced. What follows are simply the results of some initial soundings regarding the consonantal text of $\mathrm{L} 17$ in comparison with $\mathrm{L}$ and $\mathrm{A}$, and - as far as possible $-\mathrm{L}^{\mathrm{m}}$ and $2 \mathrm{p}$. They cannot claim to be representative firstfruits. They are merely amuse-bouches, suggestive of some of the kinds of fruit that may emerge from more comprehensive studies.

Breuer pulls no punches when describing the state of the consonantal text of L:

In the text of the Prophets in the Leningrad Codex there are more than 250 places in which the orthography stands in opposition to the Tiberian Masorah ... Kahle's claim that the Leningrad Codex is 'ben Asher's text', is an injustice to b. Asher. Dotan's claim, that the Leningrad Codex matches $b$. Asher's tradition, is simply incomprehensible. ${ }^{58}$

As for Samuel b. Jacob's Torah manuscript $\mathrm{L}^{\mathrm{m}}$, Breuer notes that it contains approximately 40 readings in common with $\mathrm{L}$, where both manuscripts contradict the stipulations of the Masora, and a further 40 readings erring from the Masora's stipulations where $\mathrm{L}$ did not so err. ${ }^{59}$ Likewise, 2 (the Former Prophets manuscript whose colophon revealed it to be the work of Samuel b. Jacob) shares 35 readings with $\mathrm{L}$ that deviate from the Masora, and contains an additional 125 readings that deviate from the Masora where $\mathrm{L}$ did not so deviate. ${ }^{60}$ According to these three manuscripts, therefore, the evidence suggests that $b$. Jacob was not particularly expert in aligning the plene/defective spellings of the consonantal text against the stipulations provided by the Tiberian Masora.

Initial forays into the consonantal text of L17 have been carried out from three slightly different angles. First, the orthography of Judges 17-20 in L17 was collated against the orthography of $\mathrm{L}$ and $\mathrm{A}$. The second sample examined 26 loci uncovered by Breuer in Kings, where the text of $\mathrm{L}$ disagrees with the combined witness of $\mathrm{A}, \mathrm{C}, \mathrm{D}$, and $\mathrm{S}^{1}{ }^{61}$ Finally, I have examined the locations from Judges and Samuel at which Weil (BHS apparatus) notes that the consonantal text of L stands in contradiction to its own masora ( $\mathrm{mm}$ or $\mathrm{mp}$ ). All three sets of data

58 Breuer, Keter, 6.

59 Breuer, $L^{m}$, ix.

60 Breuer, $L^{m}$, ix.

61 Breuer, Keter, 103-104. Breuer notes 27 such occurrences, but one of these (2 Kgs 12:22) is not extant in L17 due to damage to the edge of the leaf. 
will be presented before attempting to draw some conclusions therefrom.

\section{5:1 The Orthography of Judges 17-20 in L17}

The purpose of this sample was to approach the orthography of L17 on its own terms, rather than via Samuel b. Jacob's practice in L. The text of L17 over these four chapters was collated against the texts of L and A.

On five occasions L17 agreed with A, over against the text of L:

L

18:5

18:7

18:7

19:6

19:9
התצליח

ורחקים

מצדנים

ויטב

לערב וטב
L17 and $A$

התצלח

ורחוקים

מצידנים

וייטב

לערוב

By contrast, on one occasion L17 diverged from L and A's shared reading:

L17

20:43

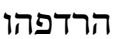

\section{$L$ and $A$}

הרדיפהו

In this sample, there were no instances where L and L17 shared a common reading over against that of $\mathrm{A}$.

\section{5:2 L's Isolated Readings in the Book of Kings}

As part of his substantial study of the text of A, Breuer collated the text of the Former and Latter Prophets in manuscripts A, C, L and $\mathrm{S}^{1}$, and the b. Hayyim edition of Miqraot Gedolot (D). He found that on approximately 180 occasions $\mathrm{L}$ has a reading not recorded in any of these other textual witnesses. Moreover, he claims that in almost all of these cases there exist masoretic notes confirming the text of A, C, D, and $S^{1}$ over against $L^{62}$. Of these isolated readings, 27 occur in the book of Kings. L17's text is illegible in one of these cases due to damage to the leaf. In the 26 extant loci, the text of L17 was consulted. In 21 of the occurrences $\mathrm{L} 17$ conforms to the majority reading of $\mathrm{A}, \mathrm{C}$,

${ }^{62}$ Breuer, Keter, 102, n.4. 
$\mathrm{D}$, and $\mathrm{S}^{1}$, rather than to the reading of $\mathrm{L}$. In the other 5 instances, however, the singular reading found in $\mathrm{L}$ is also found in L17:

\begin{tabular}{|c|c|c|}
\hline $\mathrm{A}, \mathrm{C}, \mathrm{D}$ and $\mathrm{S}^{1}$ & $\mathbf{L}$ & L17 \\
\hline חטאתיו & חטאתו ׳חטאתיו ק’ & חטאתו ־חטאתיו ק’ \\
\hline משביעך & משבעך & משבעך \\
\hline הלא & הלוא & הלוא \\
\hline מחטאת & מחטאות & מחטאות \\
\hline בגי & בגיא & בגיא \\
\hline
\end{tabular}

\section{5:3 L's 'Contra Textum' Masoretic Notes}

$\mathrm{L}$ is somewhat notorious for the relatively high proportion of occurrences where the consonantal text stands at variance with the text's masora. ${ }^{63}$ For example, the biblical text may record a plene spelling, where the masora demands a defective spelling. These contradictions occur in two slightly different manners. In many instances a particular reading deviates from that required by a mm note, where that $\mathrm{mm}$ note is not found on the same page as the reading in question. In these cases there is a contradiction between text and masora, but it is not immediately obvious. More startling are the cases where the biblical text is adorned with a mp note (and often an associated $\mathrm{mm}$ note nearby), yet the biblical text nonetheless contradicts the orthography required by the mp note. In both of these cases, Weil (in his masoretic apparatus to BHS) marked the contradiction with the footnote 'contra textum' appended to the $\mathrm{mp}$ note.

I have examined the locations from Judges and Samuel at which Weil notes that the consonantal text of $\mathrm{L}$ stands in contradiction to its masora, and compared the text of L17 to see how the latter manuscript behaves in these circumstances. ${ }^{64}$ The table below also includes the reading of $\mathrm{A}$ at these points, for further comparison. If the manuscript has a corresponding $\mathrm{mp}$ note ad loc, this has been included alongside the biblical text itself. If Weil has appended to BHS an mp note (with

63 Ernest John Revell, 'The Leningrad Codex as a Representative of the Masoretic Text', in The Leningrad Codex: A Facsimile Edition, ed. David Noel Freedman (Grand Rapids, Michigan: William B. Eerdmans, 1998), xxxv.

64 For the purposes of this initial survey, I have omitted the complex cases found at Judges 1:32 and 2 Samuel 10:7, and also the example at 2 Samuel 18:18, where the issue appears to me to be merely terminological. 
or without a corresponding mm note), not extant ad loc, but pertaining to that biblical text, a suitably abbreviated part of this note has been added in the right hand column. For ease of comparison, L17, and whichever texts with which it is in agreement, have been lightly shaded.

\begin{tabular}{|c|c|c|c|c|}
\hline Judges & $\mathbf{L}$ & L17 & $\mathbf{A}$ & $\begin{array}{l}M p / M m \text { note from } \\
\text { elsewhere in } L\end{array}$ \\
\hline 1:14 & לשאול & לשאל ׳ח' חסי65 & לשאל ׳ן' חס' & 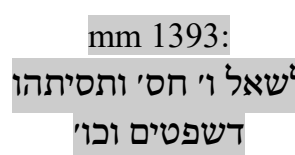 \\
\hline 18:7 & ורחקים & ורחוקים & ורחוקים ׳ב' יבאו & 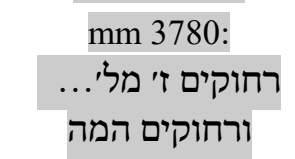 \\
\hline 1 Samuel & $\mathbf{L}$ & L17 & $\mathbf{A}$ & $\begin{array}{l}\text { Mp/Mm note from } \\
\text { elsewhere in } L\end{array}$ \\
\hline 8:8 & אתם & אתם & אותם 'ד' מל' & ד' מל' בסיפ' \\
\hline
\end{tabular}

65 The mp note at Judges 1:14 requires explanation. The mp note ad loc in A and the $\mathrm{mm}$ in L both agree that there are six occurrences of the Qal infinitive לשאל written defectively. Whence does L17 derive the figure eight? The same page $(28 / 135)$ contains the following $\mathrm{mm}$ note:

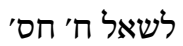

\begin{tabular}{|c|c|c|c|}
\hline Judg. 1:14 & ותסיתהו דשפטים & 1 Sam. 12:19 & כי יספנו על כל חטאתינו \\
\hline m. $8: 10$ & לשאל לו לשלום ולברכו & $1 \mathrm{Kgs} \mathrm{2:6}$ & ועשית כחכמתך \\
\hline 15:5 & ומי יסור לשאל & Ps. 78:18 & אכל לנפשם \\
\hline Job 31:30 & לשאל באלה & & \\
\hline
\end{tabular}

This is largely identical to the mm note (no. 1393) found in L. The only significant change is the addition of the lemma from 1 Kings 2:6 (italicised in the list above). This verse contains the clause: ולא־תורד שיבתו בשלם שאל (David's instruction to Solomon, regarding Joab). In this verse, שאל refers to the location, rather than being a verb. Nonetheless, it is written defectively, and contains the mp note (in L17): ב' חס ל. An associated $\mathrm{mm}$ note in L17 reveals that the other location of the defectively written word 'Sheol' is at Job 17:16. It seems likely, therefore, that the note above was intended to record all eight occurrences of the defectively written form שאל (verb or noun). To this end, the lemma from 1 Kings 2:6 was added to the longer list pertaining to the infinitive construct. The conglomerate list was imperfectly produced however, as the לשאל ח' חס' לשא was not removed from was the lemma from Job 17:16 added. 


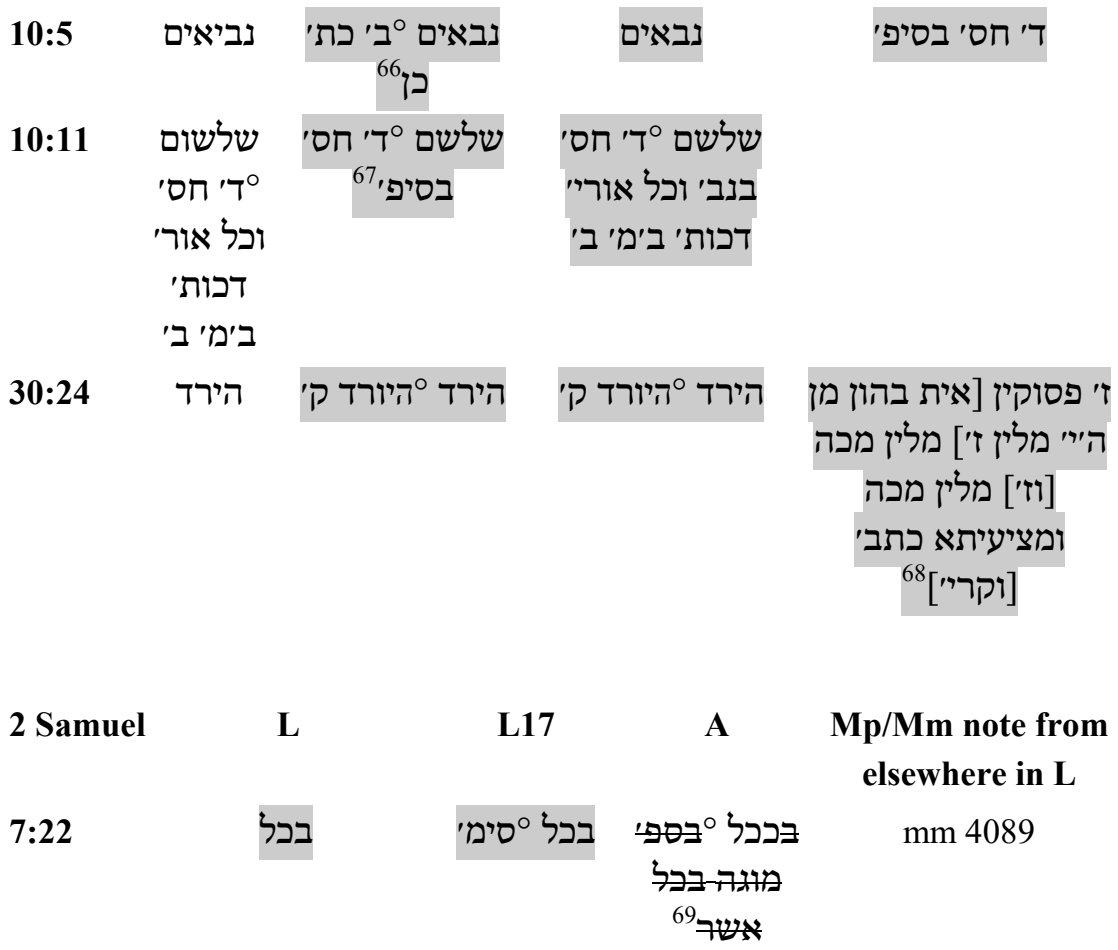

66 Prima facie this note contradicts the mp note from L: 'ד' חס' בסיפת B. Both A and L17 do indeed have four defective readings: נבאים, so the mp note in L is reliable. However, it is possible that L17's ב' כת' כן is intended to refer only to the thematically

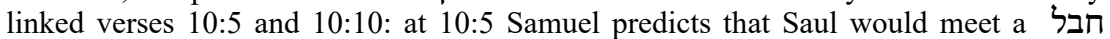
נבאים; at 10:10 Saul does indeed meet a חבל נבאים. Thus, we need not necessarily conclude that L17's mp note here is corrupt.

67 At 10:11, L17's mp note claims that there are four occurrences of שלשם spelled defectively in the book of Samuel. The equivalent note in A claims that those four occurrences are in the Prophets as a whole. As it happens, the four occurrences do all occur in Samuel, so these two notes do not contradict one another.

68 This mm note in L (no. 1594, found at 1 Sam. 13:19) claims that this verse is one of seven verses each containing fifteen words, where the central word of the verse is an instance of ketib-qere. In this instance, the central word is הירד, a defectively written Qal participle, with the definite article. Unlike L17 and A, the text of L itself contains no ketib-qere note, and hence is formally in contradiction with the note. On the other hand, in L's rescension of this masoretic tradition, Samuel b. Jacob omits the reference to 1 Samuel 30:24 (though he forgets to emend the total count to six verses rather than seven).

69 In A, בכל was originally written, but then the 'tail' was erased to turn the a כ. An mp note has been cancelled out by means of five crudely drawn vertical lines through the note, in an ink that may well be different to that of the text itself. Though difficult to read, the original note seems to have read: בספ' מוגה בכל אשר. 


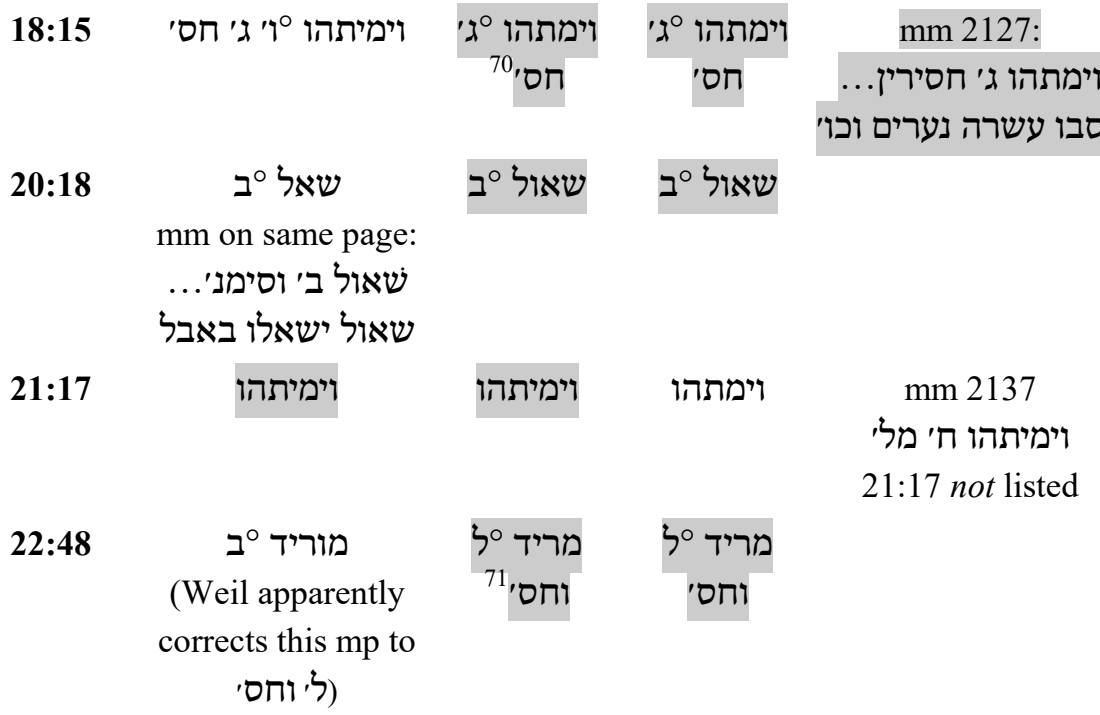

To summarise this rather sprawling set of data: we have examined eleven of the contradictions between L and L's masora in the books of Judges and Samuel. In all eleven cases the orthography of A matches that required by the masoretic comments, and hence avoids all contradiction. As for L17: in eight of these eleven cases L17's orthography matches the masoretic requirement, and hence does not contain the contradiction found in L. In seven out of these eight cases L17 contains an mp note which may have guided Samuel b. Jacob towards the masoretic orthography (in fact, in two of these seven cases he appears to have corrected an initially contradictory orthography, presumably due to the influence of the mp comment). However, in three of the eleven cases L17 contains the same orthography as L, and hence, along with $\mathrm{L}$, stands in contradiction to the stipulations of the masoretic note found in L. In 1 of these three cases L17 contains a relevant mm note on the same page (2 Samuel 7:22).

\section{5:4 Analysis}

At least three provisional conclusions may be drawn from this data, all subject to confirmation or disconfirmation by more comprehensive analysis.

70 Orthography harmonised away from plene spelling, apparently by original scribe.
71 Orthography harmonised away from plene spelling, apparently by original scribe. 
First, the evidence presented above suggests that the orthography of L17 may be closer than either L or $2 p$ to the orthography of A. Across the Former Prophets, Breuer counts 135 occurrences where the text of L deviates from the text of A, and 160 occurrences where the text of deviates from the text of $A .^{72}$ In the four-chapter sample above (Judges 17-20), the orthography of L17 differed in only one place from the orthography of A. If this text sample were representative, this would be the equivalent of about 37 deviations from the orthography of A over the entirety of the Former Prophets.

The samples above do not suggest a strongly marked genetic relationship between the consonantal text of $\mathrm{L}$ and that of $\mathrm{L} 17$ (such as, that they were both copied from a shared Vorlage). Of the 27 places where $\mathrm{L}$ has a reading not found among the rest of $\mathrm{A}, \mathrm{C}, \mathrm{D}$, and $\mathrm{S}^{1}, \mathrm{~L} 17$ shares only 5 of these singular readings. Moreover, not all of these 5 shared readings are necessarily due to a tradition shared between $\mathrm{L}$ and L17. Kennicott's compilation shows that four of these supposedly singular readings are found in many of the later manuscripts he used for his collation. ${ }^{73}$ It would be difficult to suppose that all of these later manuscripts were reliant on the text of $\mathrm{L}$ for these readings.

On the other hand, the samples above do present some slight, but intriguing, evidence suggesting that, at least at certain loci, Samuel b. Jacob did attempt to preserve particular orthographic traditions. Such appears to be the case with respect to the vocalisation - not least his unusual pronunciation of the word הירחמאלי (discussed above). Three details from the data above are suggestive in this respect:

At 1 Kings 22:16 L and L17 preserve the orthography משבעך, whereas A, C, D, and $\mathrm{S}^{1}$ read the plene spelling משביעך. Kennicott records no evidence of the defective spelling among the manuscripts he collated. Both A and $\mathrm{L}$ record the plene spelling in the parallel passage 2 Chronicles 18:15. Moreover, both L and A (but not L17) contain the mp note ' $ב$ at 1 Kings 22:16. Presumably, therefore, the mp note in A refers not only to the occurrence of the particular grammatical form, but also to the spelling. It is possible, by contrast, that the $\mathrm{mp}$ note in $\mathrm{L}$ is not intended to convey information regarding the spelling, but simply the fact that there are only two occurrences in the Hebrew Bible of the Hiphil 3ms participle of the root שבע with a 2ms object suffix.

\footnotetext{
${ }^{72}$ Breuer, $L^{m}$, ix.

73 The fifth reading is discussed below.
} 
The occurrence of the rare defective spelling in both L and L17, despite Samuel b. Jacob's knowledge of the plene spelling in the form's unique parallel in Chronicles, may suggest the transmission of a deliberate tradition at this point.

A further two agreements between the orthographies of L and L17 over against other Tiberian codices are particularly interesting because of their connection to the Babylonian biblical tradition. At 1 Kings

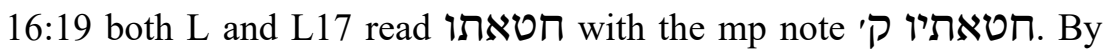
contrast, A, C, D, and $\mathrm{S}^{1}$ all read חטאתיו with no ketib-qere masoretic note. Breuer observes that, according to the Easterners-Westerners list in L's masora finalis, L (and, we may now add, L17) is following the orthography of the Easterners at this point. ${ }^{74}$

The second location in our small sample where L and L17 share a connection with the Babylonian biblical tradition is found at 2 Samuel

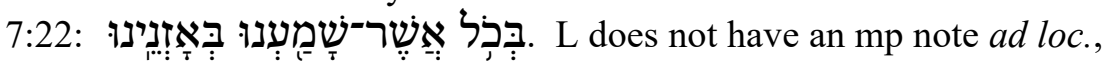
but mm note no. 4089 (at 1 Chron. 17:20, f. 338r) claims that 2 Samuel 7:22 should read ככל, whereas the parallel passage in Chronicles (1 Chron. 17:20) should read בכל כבל Hence, L's text contradicts its masora at this point. L17 also reads בכל בכל, with a long mm note at the bottom of the same leaf. First, this note presents the differences between Samuel and Chronicles, in very similar terms to $\mathrm{mm}$ no. $4089 .^{75}$ The note continues, however, by citing an Easterners-Westerners difference:

\section{למערב' דשמוא' [ככל אשר שימענו כף למד' בכל אשר שמענו ב'.}

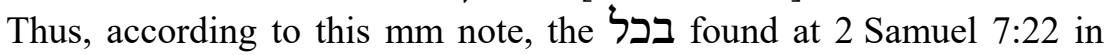
both L and L17 (against L's masora, and against the emended reading of A) reflects the Eastern-Babylonian-tradition.

\section{5:5 Conclusion}

The analysis of the small data sample thus far studied, albeit tentative, provisional, and liable to substantial modification, nonetheless presents a picture of L17 that ties in well with what is known of Samuel b. Jacob's oeuvre from elsewhere. We know from one of L's colophons (479r) that Samuel b. Jacob revered the work of b. Asher, and attempted to align his own work with that of the master masorete.

74 Breuer, Keter, 103, n.6.

75 Except, oddly and presumably mistakenly, that in the pertinent lemma for both Samuel and Chronicles, the text בכל is written! 
Thus, if it does transpire that L17's orthography is closer to that of $\mathrm{A}^{76}$ than $L$ and 2 , this will occasion no surprise per se, though it will raise further questions regarding his relative lack of success in achieving this alignment in his other manuscripts. Likewise, the evidence adduced above suggests that, though $\mathrm{b}$. Jacob does not copy his texts from a common Vorlage, he does appear to transmit traditions at various specific locations in the text. Particularly interesting are the two texts in which L and L17 share a reading linked with the Babylonian biblical tradition. Again, this tallies with our previous knowledge of the scribe: at least two lines of evidence already connect this scribe with the Eastern biblical tradition. Most obviously, his Torah codex $\mathrm{L}^{\mathrm{m}}$ preserves in the mm many masoretic notes from the Babylonian tradition. Moreover, in the division of certain words into two he apparently follows the Babylonian rather than the Tiberian tradition. ${ }^{77}$

Thus, these shared Babylonian readings in L and L17 cohere well with the known facts. Whether or not these two isolated examples prove to be the tip of a larger iceberg will require a much fuller study of the relationship between L and L17. Might it be that a proportion of L's notorious deviations from the stipulations of the Masora are due to his conscious preservation of readings from the Babylonian biblical tradition? Perhaps, or perhaps not. But it is only now, with L17's authorship clarified, and the text readily available online, that such questions can begin to be asked and answered.

76 Whether $\mathrm{A}$ is the work of $\mathrm{b}$. Asher, or simply our closest extant codex to the $\mathrm{b}$. Asher tradition, is immaterial here.

77 Dotan, 'Hatṭin', 163. 